\title{
Equol, a Dietary Daidzein Gut Metabolite Attenuates Microglial Activation and Potentiates Neuroprotection In Vitro
}

\author{
Lalita Subedi ${ }^{1}$, Eunhee Ji ${ }^{1}$, Dongyun Shin ${ }^{1}$, Jongsik Jin ${ }^{2}$, Joo Hong Yeo ${ }^{3}$ and \\ Sun Yeou Kim 1,4,5,* \\ 1 College of Pharmacy, Gachon University, \#191, Hambakmoero, Yeonsu-gu, Incheon 21936, Korea; \\ subedilali@gmail.com (L.S.); ehji@gachon.ac.kr (E.J.); dyshin@gachon.ac.kr (D.S.) \\ 2 Department Oriental Medicine Resources, College of Environmental \& Bioresources Sciences, \\ Chonbuk National University, Jeonju City 54896, Korea; jongsik.jin@jbnu.ac.kr \\ 3 National Institute of Biological Resources, Environmental Research Complex, 42 Hwangyeong-ro, \\ Seo-gu, Incheon 22689, Korea; naasyeo@korea.kr \\ 4 Gachon Medical Research Institute, Gil Medical Center, Inchon 21565, Korea \\ 5 Gachon Institute of Pharmaceutical Science, Gachon University; \#191 Hambakmoe-ro, \\ Yeonsu-gu, Incheon 21565, Korea \\ * Correspondence: sunnykim@gachon.ac.kr; Tel.: +82-32-820-4931; Fax: +82-32-820-4932
}

Received: 6 November 2016; Accepted: 21 February 2017; Published: 27 February 2017

\begin{abstract}
Estrogen deficiency has been well characterized in inflammatory disorders including neuroinflammation. Daidzein, a dietary alternative phytoestrogen found in soy (Glycine max) as primary isoflavones, possess anti-inflammatory activity, but the effect of its active metabolite Equol (7-hydroxy-3-(4'-hydroxyphenyl)-chroman) has not been well established. In this study, we investigated the anti-neuroinflammatory and neuroprotective effect of Equol in vitro. To evaluate the potential effects of Equol, three major types of central nervous system (CNS) cells, including microglia (BV-2), astrocytes (C6), and neurons (N2a), were used. Effects of Equol on the expression of inducible nitric oxide synthase (iNOS), cyclooxygenase (COX-2), Mitogen activated protein kinase (MAPK) signaling proteins, and apoptosis-related proteins were measured by western blot analysis. Equol inhibited the lipopolysaccharide (LPS)-induced TLR4 activation, MAPK activation, NF-kB-mediated transcription of inflammatory mediators, production of nitric oxide (NO), release of prostaglandin E2 (PGE-2), secretion of tumor necrosis factor- $\alpha$ (TNF- $\alpha$ ) and interleukin 6 (IL-6), in Lipopolysaccharide (LPS)-activated murine microglia cells. Additionally, Equol protects neurons from neuroinflammatory injury mediated by LPS-activated microglia through downregulation of neuronal apoptosis, increased neurite outgrowth in N2a cell and neurotrophins like nerve growth factor (NGF) production through astrocytes further supporting its neuroprotective potential. These findings provide novel insight into the anti-neuroinflammatory effects of Equol on microglial cells, which may have clinical significance in cases of neurodegeneration.
\end{abstract}

Keywords: Equol; phytoestrogen; neuroinflammation; apoptosis; neuroprotection

\section{Introduction}

Nutraceuticals may be foods or nutrients that provide health benefits, including the prevention or treatment of a disease [1]. Nutraceuticals and their active metabolites have been reported to possess a variety of biological activities [2]. Fewer adverse effects, easy availability and promising effects of nutraceuticals and phytochemicals are advantages that drive the development of safe, effective, and economic new drugs for better health [3]. 
Among those dietary foods that have pharmacologically active metabolites, soybean (Glycine max L.), which is commonly consumed in traditional Asian food, is a major source of oil and protein in the human and animal diet [4]. It is one of the natural substitutes for the treatment of a variety of hormone-dependent and independent disorders in humans [5]. Biologically active soy phytoestrogens and their potential effects against breast, prostate, and colon cancer, obesity, cardiovascular disease, Alzheimer's disease, and osteoporosis have made them the subject of research for a long time [5,6]. Isoflavones are phytoestrogens with potent estrogenic activity; Genistein, Daidzein, and glycitein are the most active of the isoflavones found in soybeans $[7,8]$. Soy metabolites, namely isoflavones, unsaturated fatty acids, and saponins, possess great potential for human health due to their antioxidant and anti-carcinogenic activity [9]. Soy isoflavones, or phytoestrogens from soy, have been shown to be strongly associated with anticancer activity and inhibition of the epidermal growth factor receptor tyrosine kinase [10]. Furthermore, Schreihofer et al. reported that pretreatment with soy phytoestrogens might mimic in vitro neuroprotective effects [11]. In addition, Ma W et al. suggested that Genistein may possess neuroprotective properties through its anti-inflammatory activity [12].

Glycosides, like Daidzin (Daidzein glycoside) and Genistin (Genistein glycoside) [13], are biologically active candidates for a variety of human ailments $[8,14,15]$. Not all but about $20 \%-35 \%$ of Western and 50\%-55\% Asian adult populations are Equol producers [16]. They can metabolize Daidzein by gut microflora to an estrogenic metabolite called Equol [7-hydroxy-3-(4'-hydroxyphenyl)-chroman], which exhibits biological properties that exceed those of its precursor [17-20]. Equol is similar in structure to the human female hormone, $17-\beta$-estradiol [21]. It can bind to both alpha and beta estrogen receptors, where it mimics the action of estrogens on target organs, thereby exerting health benefits when used in some hormone-dependent diseases [21,22]. Equol displays strong antioxidant properties, as well as the ability to regulate cell cycles $[23,24]$. Interestingly, soybean was reported to act as an acetyl cholinesterase inhibitor and was found to improve memory in rodents using different maze models. In addition, the neuroprotective effect of Equol in transient focal cerebral ischemia was reported $[25,26]$.

Oxidative stress and neuroinflammation are believed to play key roles in nigrostriatal dopaminergic neuron demise [27]. Neuroprotective effects of estrogens have been widely reported in a number of neuronal cells [28]. Besides having potential as various disease treatments, estrogen has many acute and long-term adverse effects, including headaches and migraines [29]. Estrogen therapy can be dangerous to those who are prone to blood clotting and it can increase the risk of uterine, breast and endometrial cancer, liver complications, gallstones and cholecystectomy [30]. For this reason, research into an estrogen-like phytoestrogen without toxicities is ongoing. Soy and soy products such as Genistein and Daidzein have previously been reported to possess the ability to treat various CNS disorders including depression, Alzheimer's, epilepsy, dementia etc. Moreover, Daidzein and its metabolites are the major interest of research these days for their anti-neuroinflammatory efficacy [31]. As Equol and O-desmethyl angolensin (ODMA) are the major intestinal metabolites of Daidzein, ODMA is reported to have little potential to bind with the estrogen receptors (ERs) in comparison to that of Daidzein and Equol [32,33]. Estrogen receptor (ER) beta agonists have been demonstrated to possess anti-inflammatory properties in inflammatory disease models [34]. Moreover, Equol, being a strong ER- $\beta$ agonist, can not only provide the positive therapeutic value as hormonal therapy but also help to control various neurodegenerative disorders [34]. Hence, exploring the biological activity of Daidzin and its metabolite especially Equol could be of great interest for neuroinflammatory disorders.

Microglial cells, the immune resident cells of the brain, are principally responsible for immune defense in the CNS. However, under pathological conditions, microglia cells are over-activated and produce a variety of proinflammatory mediators, including NO. For the in vitro experiment we used Lipopolysaccharide (LPS) as a neuroinflammation inducer that is responsible for neurodegeneration. LPS is a bacterial endotoxin that can trigger the inflammation via microglia and astrocyte activation, followed by increased production of COX-2, iNOS, NO and proinflammatory cytokine such as TNF- $\alpha$ and IL-6, which ultimately cause damage to DA neuron that causes various neuroinflammatory and 
neurodegenerative disease. [35,36]. In this study, we evaluated Equol and its related compounds for inhibitory effects on LPS-activated NO production in BV-2 cells. Together with the result we further hypothesized that Equol, a gut metabolite of Daidzein, might have more anti-neuroinflammatory potential than Daidzein. The detailed mechanism has not been well established and its neuroprotective role in vitro is not yet determined. Therefore, in this study, we are to determine whether Equol attenuates proinflammatory responses in LPS-stimulated BV-2 microglia and attempted to clarify the possible mechanisms of action. LPS is an endotoxin found in the cell wall of gram-negative bacteria and it is extensively used to induce the neuroinflammation in experimental models both in in vivo and in vitro [37]. In this study we used LPS obtained from the Escherichia coli strain to activate the BV2 microglial cells.

\section{Experimental Section}

\subsection{Reagents}

Chemicals used in cell culture experiments including Dulbecco's modified Eagle medium (DMEM), fetal bovine serum (FBS), and penicillin-streptomycin were obtained from Invitrogen (Carlsbad, CA, USA). LPS, N-monomethyl-L-arginine (NMMA), and (R, S)-Equol were purchased from LC Laboratories (Cat. No.: E-5880). Enzyme link immune sorbent assay (ELISA) development kit, TNF- $\alpha$, IL-6, PGE-2, and NGF were purchased from R\&D Systems (Minneapolis, MN, USA). Primary and secondary antibodies for iNOS, COX-2, pERK, ERK, pJNK, JNK, pp38, p38, Bax, Bcl-2, cleaved caspase-3, and tubulin were purchased from Cell Signaling (Beverly, MA, USA). All other chemicals and reagents were purchased from Sigma Chemical (St. Louis, MO, USA) unless otherwise stated.

\subsection{Cell Culture}

Three different cell lines microglia (BV2), astrocytes (C6) and Neuroblastoma (N2a) were used to study the anti-neuroinflammatory and neuroprotective effect of Equol. Unlike other studies that used particular cell types for the study of the anti-neuroinflammatory efficacy of different targets, the use of three different cell lines in this study represents the complete CNS environment. The murine BV2 cell lines were kindly provided as gift samples from E. Choi at Korea University (Seoul, South Korea). We purchased the C6 glioma cells from the Korean Cell Line Bank (Seoul, Korea), whereas the N2a cells were obtained from American Type Culture Collection (Manassas, VA, USA). All cell culture and maintenance procedure was done as described previously [38].

\subsection{Cell Viability Assay}

3-(4,5-dimethylthiazol-2-yl)-2,5-diphenyl-tetrazolium bromide (MTT) assay was used to determine the cell viability of BV2 cells $24 \mathrm{~h}$ after the exposure with LPS in the presence or absence of different concentrations of Equol as described previously [38] with some modification. Supernatant or medium was removed from the treated plate and MTT solution was added in the cell and it was incubated for an hour. After incubation the solution was also removed and DMSO was added to convert blue stained cells (MTT) to Formazan.

\subsection{Nitric Oxide (NO) and Proinflammatory Cytokine Measurement}

The inhibitory effect of Equol on LPS-stimulated NO synthesis and proinflammatory cytokine release was studied using BV-2 microglial cells. BV-2 cells were plated into a 96well plate $\left(4 \times 10^{4}\right.$ cells/well) and treated with $100 \mathrm{ng} / \mathrm{mL}$ LPS [37], in the presence or absence of different concentrations of Equol, for $24 \mathrm{~h}$ with NG-mono-methyl-L-arginine (L-NMMA), a well-known nitric oxide synthase (NOS) inhibitor [39] as a positive control. Nitrite level was measured in the culture media using Gries reagent as described previously [38] with some modification. Equal amount of treated cells supernatant or conditioned medium, i.e., $50 \mu \mathrm{L}$ was added to $50 \mu \mathrm{L}$ of Gries reagent and 
the colorimetric changes were measured at $540 \mathrm{~nm}$ wavelength in the microplate reader taking Nano2 as a standard.

\subsection{Measurement of PGE-2, TNF- $\alpha$, and IL-6 Production}

The level of PGE-2, TNF- $\alpha$, and IL- 6 production were measured in culture medium of LPSstimulated BV2 cells in the presence or absence of Equol at different concentrations. Following $24 \mathrm{~h}$ of incubation, the levels of PGE-2, TNF- $\alpha$, and IL- 6 was measured. PGE-2 was measured using a competitive ELISA (Cayman Chemical, Ann Arbor, MI, USA) as described previously [38].

\subsection{NF- $\kappa B$ Assay}

Nuclear extracts from the LPS-stimulated microglia were prepared using a Nuclear Extract Kit (Active Motif, Carlsbad, CA, USA) according to the manufacturer's protocol. Protein levels of NF-KB, I $\kappa \mathrm{B}$ and $\mathrm{p}-\mathrm{I} \kappa \mathrm{B}$ were evaluated by western blot analysis.

\subsection{Western Blot Analysis}

BV2 cells were seeded in a 6-well plate at the density of $6 \times 10^{5}$ cells/well and treated with 5,10 , $20 \mu \mathrm{M}$ and activated with LPS (100 ng/mL) and incubated for $24 \mathrm{~h}$. Cells were washed with ice-cold PBS and collected using a scraper. Collected cells were lysed with lysis buffer ( $50 \mathrm{mM}$ Tris-HCl, $\mathrm{pH}$ 8.0, $0.1 \%$ SDS, $150 \mathrm{mM} \mathrm{NaCl}, 1 \% \mathrm{NP}-40,0.02 \%$ sodium azide, $0.5 \%$ sodium deoxycholate, $100 \mu \mathrm{g} / \mathrm{mL}$ PMSF, $1 \mathrm{~g} / \mathrm{mL}$ approtinin) and the proteins obtained were estimated using Bradford's assay in order to get $30 \mu \mathrm{g}$ of it from each group. Equol protein was loaded and separated by $10 \%$ SDS-PAGE gel electrophoresis, transferred to nitrocellulose membranes, blocked with $5 \%$ skim-milk and incubated overnight with primary antibodies against tubulin (Sigma-Aldrich, St. Louis, MO, USA, Cat. No.: T5168), iNOS (Bioscience Cat. No.: 610333, COX-2 (Santa Cruz, CA, USA Cat. No.: sc-1745), ERK (Cell Signaling, Danvers, MA, USA Cat. No.: 9107s), pERK (Cell Signaling Cat. No.: 5013s), JNK (Cell Signaling Cat. No.: 9252s), pJNK (Cell Signaling Cat. No.: 4671s), p38 (Cell Signaling Cat. No.: 8690s), pP38 Cell Signaling Cat. No.: 9211s), cleaved caspase-3 (Cell Signaling Cat. No.: 9661s), Bax (Santa Cruz Cat. No.: Sc-493), and Bcl-2 (Santa Cruz, CA, USA, Cat. No.: Sc492) at $4^{\circ}$ C. Membranes were then incubated with respective horseradish peroxidase-conjugated secondary antibodies and protein bands were visualized using enhanced chemiluminescence reagent using the Chemi DocXRS+ imaging system (Bio-Rad, Hercules, CA, USA). Densitometry analysis of the bands was done by using Image Master ${ }^{\mathrm{TM}}$ 2D Elite software (version 3.1, Amersham Pharmacia Biotech, Buckinghamshire, UK) as described previously [38].

\subsection{Neurite Outgrowth Assay}

For neurite outgrowth assay, N2a cells were seeded onto 12 well plates at a density of $6 \times 10^{5}$ cells/well and treated with Equol for $24 \mathrm{~h}$ [38]. The extent of neurite outgrowth was determined by measuring neurite lengths of N2a cells using IncuCyte imaging system from zero to $24 \mathrm{~h}$ of treatment in each $2 \mathrm{~h}$ interval (Essen Instruments, Ann Arbor, MI, USA) as previously reported [38].

\subsection{NGF Assay}

C6 glioma cells were seeded onto 24 well plates at a density of $1 \times 10^{5}$ cells/well and treated with serum-free DMEM and the different concentrations of Equol for $24 \mathrm{~h}$. Cultured media was used to measure the amount of NGF released into the medium using an ELISA development kit as previously described [38].

\subsection{Statistical Analysis}

All experimental data are represented as mean \pm SEM. Level of significance were determined using one-way ANOVA, followed by the Newman-Keuls post hoc test, using GraphPad Prism 5 
(GraphPad Software Inc., La Jolla, CA, USA). $p<0.05$ was set as statistically significant. For the reproducibility of the results, each experiment was performed in triplicate.

\section{Results}

\subsection{Effect of Daidzein and Its Derivatives on NO Production in LPS-Stimulated BV-2 Cells}

An increase in NO production has been believed to be a biomarker for inflammation, especially neuroinflammation and related disease conditions. We performed the screening of Daidzin and its derivative including Equol for their inhibitory activity on NO production in LPS-activated BV2 cells. LPS increased the NO production from $3.77 \pm 0.25$ in the control to $45.61 \pm 0.52$ in the LPS treated group. However, $20 \mu \mathrm{M}$ of Daidzin, Daidzein, Genistin, Genistein and Equol reduced the NO production to $40.97 \pm 2.00,13.72 \pm 0.38,44.88 \pm 0.25,6.74 \pm 0.24$ and $7.73 \pm 0.11 \mu \mathrm{M}$, respectively, in LPS stimulated BV2 cells. Genistein showed better activity at higher concentration, but at the same time it showed almost $40 \%$ cellular toxicity to BV2 cells, and because of this reason the NO production value is lower than Equol. Also, among the tested compounds, Equol showed the most potent inhibitory effect on NO production in LPS-stimulated BV-2 cells as shown in Figure 1A,B. Therefore, Equol is the most potent inhibitor of NO production among all derivatives. We found that Daidzein and related compounds showed promising effects on inhibition of NO production, providing the clue for the anti-inflammatory activity of Daidzein and its related compounds among them, Equol showed the most potent inhibitory effect on NO production in LPS-stimulated BV-2 cells as shown in Figure 1A,B.

(A)

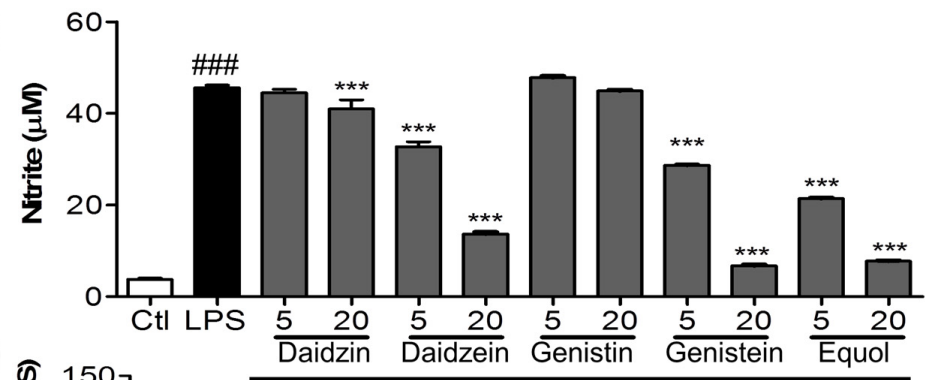

(B)

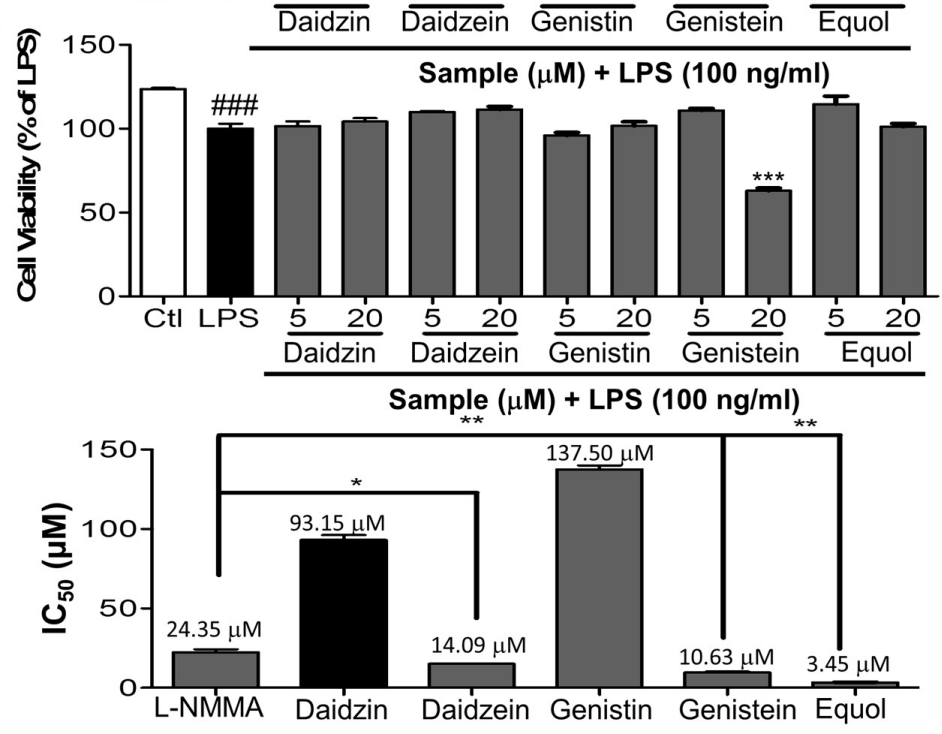

Figure 1. Effects of Equol and its derivatives on NO production in LPS-stimulated BV-2 cells. BV-2 cells were pretreated with 5, and $20 \mu \mathrm{M}$ of Equol and its derivatives for $30 \mathrm{~min}$ and stimulated with LPS (100 ng/mL) for $24 \mathrm{~h}$. (A) NO Production Assay; (B) Cell viability on BV-2 microglia was determined using an MTT assay; (C) $\mathrm{IC}_{50}$ value graph for Equol and its derivatives. All data are presented as the mean \pm SEM of three independent experiments. ${ }^{*} p<0.05,{ }^{* *} p<0.01$ and ${ }^{* * *} p<0.001 \mathrm{vs.} \mathrm{LPS-treated}$ group and ${ }^{\# \#} p<0.001$ vs. untreated control group. 
3.2. Dose Response Effect of Equol on NO Production, iNOS and COX-2 Expression and TLR4 Inactivation in LPS-Stimulated BV-2 Cells

Among various proinflammatory factors, NO is a harmful product released from activated microglia. As LPS is a TLR4 agonist, it activates this receptor and then initiates the inflammatory cascades in the microglial cells. Pretreatment of cells with Equol effectively decreased the LPS-induced TLR4 activation (Figure 2F,G) as well as NO production in BV-2 murine microglia cells without cellular toxicity (Figure 2A,B). A well-known inducible nitric oxide synthase inhibitor, NMMA [39], has an IC50 value of $24.35 \mu \mathrm{M}$, whereas Equol displayed an IC50 value of $3.00 \mu \mathrm{M}$ for inhibition of NO production by LPS activated BV-2 cells (Figure 2A). This signified that the inhibitory effect of Equol was more potent than that of NMMA at a dose of $10 \mu \mathrm{M}$. Besides reducing NO production induced by LPS, Equol increased the viability of cells against LPS-induced cell death, suggesting a neuroprotective effect in LPS-mediated neuroinflammatory conditions. Additionally, Equol reduced the expression of iNOS and COX-2, as shown in Figure 2C-E. Equol inhibited the expression of iNOS and COX-2 by $78.12 \% \pm 2.09 \%, 57.06 \% \pm 2.76 \%, 25.59 \% \pm 4.79 \%$ and $81.10 \% \pm 1.39 \%, 72.36 \% \pm 2.60 \%$, $50.88 \% \pm 0.74 \%$ at the concentration $5,10,20 \mu \mathrm{M}$, respectively. The effect of Equol at $20 \mu \mathrm{M}$ is better than that of Daidzein as shown in Figure 2C-E).NO and PGE-2 are catalyzed by iNOS and COX-2, which are key neuroinflammatory enzymes in the brain. Equol dose dependently reduced the expression of iNOS and COX-2 in BV-2 microglia, displaying an inhibitory effect on NO and PGE-2 production. These data suggested that Equol may have significant anti-inflammatory properties in LPS-stimulated BV-2 cells. As LPS is a TLR4 receptor agonist, we checked the role of Equol and SP610025 for TLR4 inactivation. SP610035 did not alter the receptor expression, whereas Equol reduced its expression to $79.63 \% \pm 0.47 \%$.

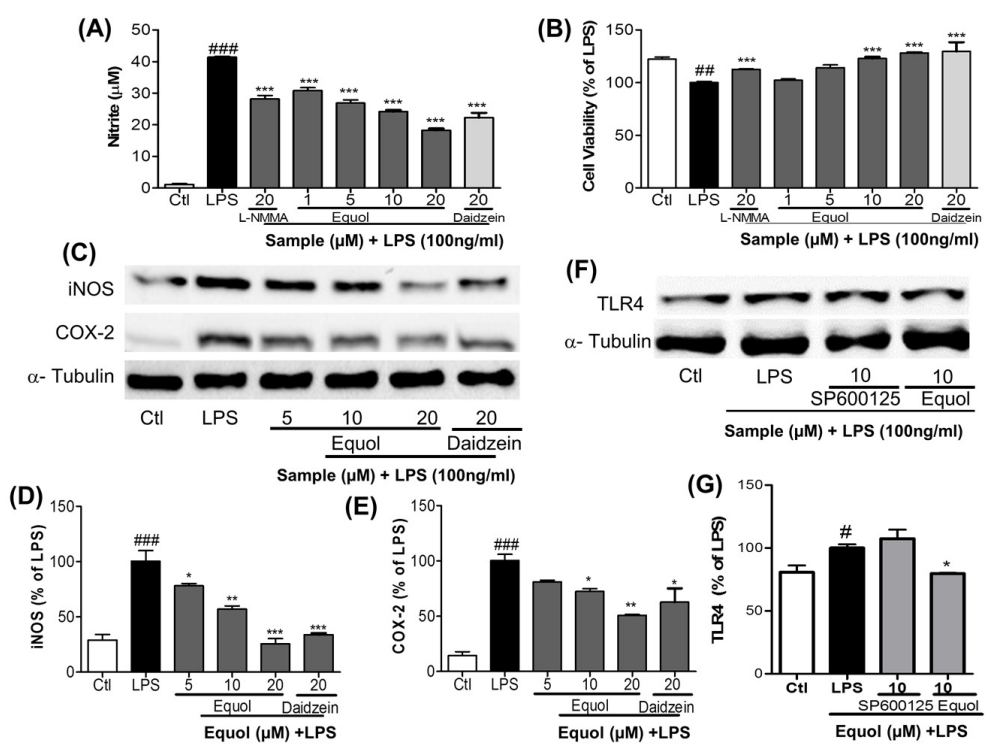

Figure 2. Effect of Equol on NO production, cell viability, and expression of iNOS, COX-2 and TLR4 expression in LPS-stimulated BV-2 cells. BV-2 cells were pretreated with various concentrations of Equol $(\mu \mathrm{M})$ for $30 \mathrm{~min}$, followed by treatment with LPS $(100 \mathrm{ng} / \mathrm{mL})$ for an additional $24 \mathrm{~h}$ to measure NO and MTT. $6 \mathrm{~h}$ treatment and LPS activation was used to measure iNOS and COX-2 expression via western blot analysis. (A) NO production measurement in LPS stimulated BV-2 cells. NMMA $(20 \mu \mathrm{M})$ was used as a positive control; (B) Cell viability of BV-2 microglia following treatment with compounds with or without LPS; (C) Expression of iNOS and COX-2 in murine microglia; (D,E) Densitometric analysis of iNOS and COX-2 proteins; (F) Activation of TLR4 expression (G) Densitometric analysis for TLR4. $\alpha$-Tubulin was used as the loading control. All data are presented as the mean $\pm \mathrm{SEM}$ of three independent experiments. ${ }^{*} p<0.05,{ }^{* *} p<0.01,{ }^{* * *} p<0.001$ vs. LPS-treated group and ${ }^{\#} p<0.05$, \#\# $p<0.01,{ }^{\# \# \#} p<0.001$ vs. untreated control group. 


\subsection{Effect of Equol on LPS-Induced MAPK Signaling in LPS-Stimulated BV-2 Cells}

To further confirm the anti-inflammatory properties, we determined the effect of Equol on MAPK family modulation. In order to evaluate the effect of Equol on phosphorylation of p38, ERK, and JNK, we quantified their expressions via western blot analysis. Western blot analysis was carried out using the phosphorylated and total forms of antibodies against MAPKs (p38, ERK, and JNK). BV-2 cells were pretreated with different concentrations of Equol, followed by LPS stimulation for $30 \mathrm{~min}$. Equol increased the phosphorylation of ERK, whereas the effect was opposite in the cases of p38 and JNK phosphorylation as shown in Figure 3A-D. Equol reduced the expression of phosphorylated p38 by $82.98 \% \pm 2.67 \%, 79.10 \% \pm 1.77 \%$ and $77.89 \% \pm 2.32 \%$ at the concentration of 5,10 and $20 \mu \mathrm{M}$ respectively. Similarly, inhibition of JNK phosphorylation was $47.60 \% \pm 5.00 \%, 38.87 \% \pm 2.02 \%$ and $25.05 \% \pm 3.80 \%$ at the same concentration of Equol. Unlikely, Equol concentration dependently increased the phosphorylation of ERK by $192 \% \pm 2.17 \%, 240 \% \pm 5.51 \%$ and $299.50 \% \pm 2.57 \%$ at 5, 10 and $20 \mu \mathrm{M}$ respectively. We compared the effect of Equol with well-known JNK inhibitor SP610025 to inhibit the JNK phosphorylation and TNF- $\alpha$ secretion in LPS-activated BV2 cells. In the treatment of same concentration of Equol and JNK inhibitor, they inhibit the phosphorylation of JNK by $79.11 \% \pm 0.45 \%$ and $89.04 \% \pm 1.87 \%$ respectively. Similarly, in the same condition, Equol and SP610025 inhibit the TNF- $\alpha$ production by $48.20 \% \pm 9.37 \%$ and $37.98 \% \pm 5.51 \%$. Equol showed similar efficacy to inhibit the phosphorylation of JNK and TNF- $\alpha$ secretion in comparison to that of SP610025 as shown in Figure 3E-G. These data suggested that Equol could modulate the MAPK signaling by, in particular, inhibiting the JNK phosphorylation.
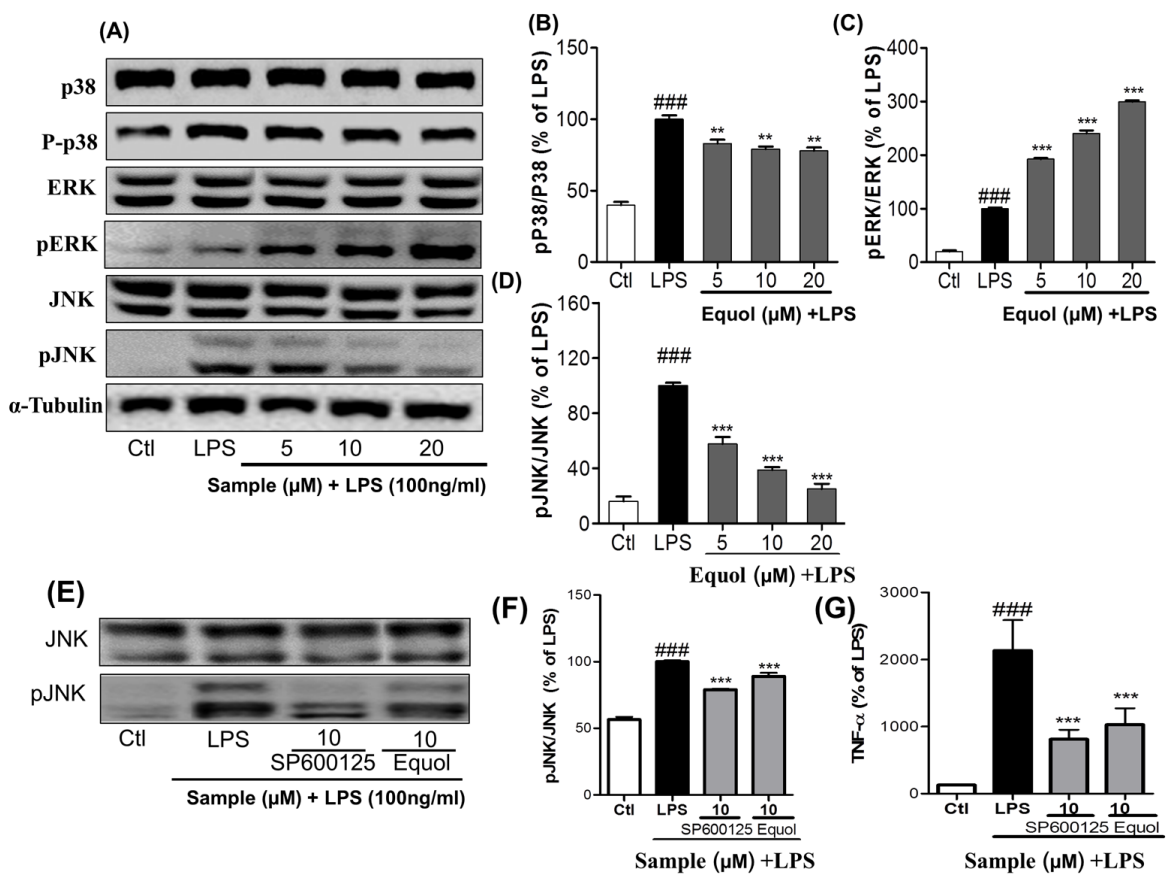

Figure 3. Effect of Equol on LPS-induced MAPK signaling in BV-2 cells. BV-2 cells were pretreated with or without Equol $(\mu \mathrm{M}) 30 \mathrm{~min}$ prior to LPS $(100 \mathrm{ng} / \mathrm{mL})$ stimulation. Activated cells were incubated for 30 min. (A) expression of pP38, P38, pJNK, JNK, and pERK, ERK; (B-D) Band intensities for pP38/P38, $\mathrm{pERK} / \mathrm{ERK}$, and $\mathrm{pJNK} / \mathrm{JNK}$ as percentage of the LPS-treated group (set as 100\%); (E) Phosphorylation of JNK to compare between Equol and SP600125 (F) Band intensities for pJNK/JNK (G) Secretion of TNF- $\alpha$ in $24 \mathrm{~h}$ LPS and compounds (Equol and SP600125) treated supernatant was measured using ELISA assay kit. SP600125 (JNK inhibitor) was used to compare the effect of Equol. All data are presented as the mean \pm SEM of three independent experiments. ${ }^{* *} p<0.01,{ }^{* * *} p<0.001$ vs. LPS-treated group and ${ }^{\# \#} p<0.001$ vs. untreated control group. 


\subsection{Effect of Equol on LPS-Induced NF-кB Activation in Murine Microglia Cells}

The effects of Equol on NF-KB activity were investigated using an NF- $\mathrm{kB}$ kit and western blot analysis as shown in Figure 4A-D.LPS significantly enhanced the expression of nuclear NF- $\mathrm{kB}$ in microglia. The increase in NF- $\mathrm{kB}$ activity was decreased significantly by pretreating cells with Equol at concentrations of 10 and $20 \mu \mathrm{M}$. It was reduced to $85.87 \% \pm 0.45 \%$ and $90.02 \% \pm 1.50 \%$ at those treated concentration. NF- $\mathrm{KB}$ is inactivated in the cytosol by binding to IкB and becomes active through translocation into the nucleus preceded by LPS-induced proteolytic degradation of IKB [37]. As shown in Figure $4 \mathrm{~A}, \mathrm{I} \kappa \mathrm{B}$ was phosphorylated and degraded $1 \mathrm{~h}$ after LPS treatment. Pretreatment of BV-2 microglia cells with Equol $(10$ and $20 \mu \mathrm{M})$ decreased the phosphorylation and degradation of IKB in response to LPS, indicating that the subsequent NF- $\mathrm{KB}$ inactivation was induced by Equol as shown in Figure 4C,D.
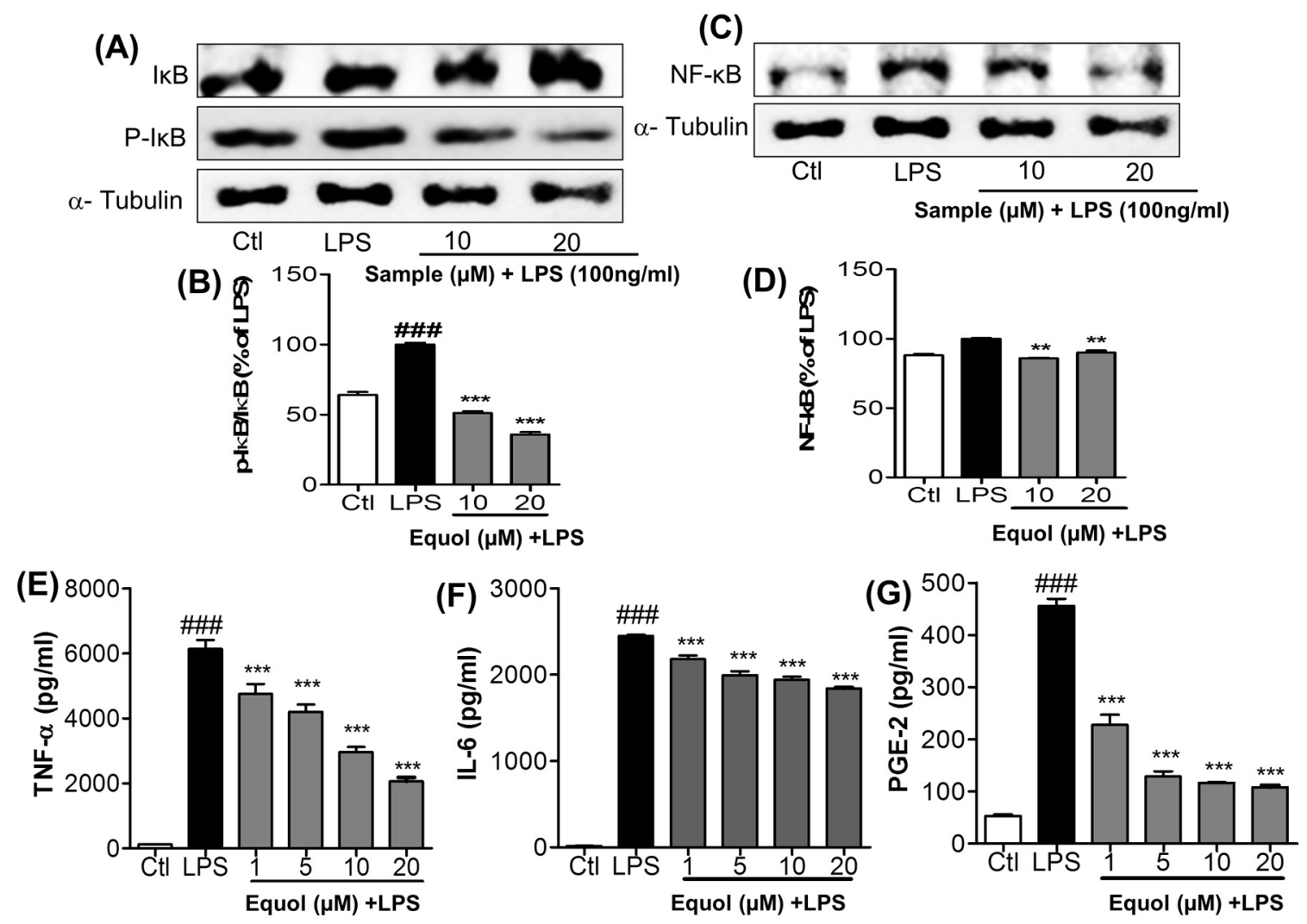

Figure 4. Effect of Equol on LPS-induced NF- $\mathrm{B}$ activation and pro-inflammatory cytokines (TNF- $\alpha$, IL-6) and PGE-2 secretion in BV-2 cells. BV-2 microglial cells were pretreated with 1, 5, 10, or $20 \mu \mathrm{M}$ of Equol for $30 \mathrm{~min}$ and stimulated with LPS (100 ng/mL) for $1 \mathrm{~h}$ for NF-kB related proteins and $24 \mathrm{~h}$ for secreted cytokines measurement. Nuclear extracts were prepared using a nuclear extraction kit.

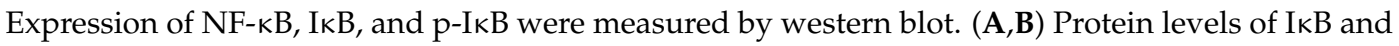
$\mathrm{p}-\mathrm{I} \kappa \mathrm{B}$ and their band intensity, respectively; (C,D) NF- $\kappa \mathrm{B}$ expression and its densitometric analysis. $\alpha$-Tubulin was used as the loading control. The culture media was subsequently collected to measure the quantity of PGE-2, TNF- $\alpha$, and IL- 6 released by the cells; (E-G) secretion of TNF- $\alpha$, IL- 6 and PGE-2 in supernatant was measured using ELISA assay kit. Data are presented as mean \pm SEM of three independent experiments performed in triplicate. ${ }^{* *} p<0.01,{ }^{* * *} p<0.001 \mathrm{vs}$. LPS-treated group and \#\#\# $p<0.001$ vs. untreated control group.

\subsection{Effect of Equol on TNF- $\alpha$, IL-6, andPGE2 Production in LPS-Stimulated BV-2 Cells}

Initiation of the inflammatory cascade produces many inflammatory mediators and proinflammatory cytokines, including TNF- $\alpha$ and IL-6. Production of proinflammatory cytokines 
further worsens the inflammatory cascade in neuroinflammatory diseases. Inhibition of the proinflammatory cytokines produced by activated microglia is necessary for neuroprotection. TNF- $\alpha$ was increased from $2.07 \% \pm 0.01 \%$ over control to $100 \% \pm 7.95 \%$ over control after 24 h of LPS treatment. It was then reduced to $77.48 \% \pm 8.50 \%, 68.57 \% \pm 6.17 \%, 48.29 \% \pm 4.47 \%$, and $33.63 \% \pm 3.46 \%$ after Equol $(1,5,10$, and $20 \mu \mathrm{M})$ treatment with LPS respectively as shown in Figure 4E. Similarly, LPS-induced IL-6 production increased from $0.69 \pm 0.068$ to $100 \pm 0.82 \mathrm{pg} / \mathrm{mL}$ after $24 \mathrm{~h}$ of LPS activation and Equol decreased its production concentration dependently and about $25 \%$ inhibition at $20 \mu \mathrm{M}$ as shown in Figure 4F. PGE-2 from culture medium was increased from $53.12 \pm 0.88 \mathrm{pg} / \mathrm{mL}$ in the control group to $455.6 \pm 4.30 \mathrm{pg} / \mathrm{mL}$ after $24 \mathrm{~h}$ of exposure to LPS. PGE-2 synthesis was decreased to $227.52 \pm 6.05 \mathrm{pg} / \mathrm{mL}, 128.78 \pm 3.08 \mathrm{pg} / \mathrm{mL}, 116.66 \pm 0.33 \mathrm{pg} / \mathrm{mL}$, and $108.06 \pm 1.16 \mathrm{pg} / \mathrm{mL}$ after treatment with Equol at concentrations of 1, 5, 10, and $20 \mu \mathrm{M}$, respectively as shown in Figure 4G.

Reduced proinflammatory cytokines, TNF- $\alpha$ and IL-6, as well as PGE-2production, in LPS activated BV-2 cells as shown in Figure $4 \mathrm{E}-\mathrm{G}$, further indicates the strong anti-inflammatory potential of Equol.

\subsection{Effect of Equol on Activated Microglia-Induced Neurotoxicity in N2a Cells}

BV-2 cells were treated with Equol and with or without LPS (100 ng/mL) for $24 \mathrm{~h}$. After $24 \mathrm{~h}$ of treatment, the treated media was collected carefully and transferred to N2a cells for another $24 \mathrm{~h}$. Cell viability in N2a cells was measured using an MTT assay. More N2a cells treated with Equol survived than those that were only treated with LPS. Cell viability was measured as percentage of LPS; Equol increased the cell viability by $110.88 \% \pm 4.94 \%, 131.03 \% \pm 5.28 \%, 178.89 \% \pm 9.49 \%$, and $219.13 \% \pm 3.97 \%$ at the concentrations of $1,5,10$, and $20 \mu \mathrm{M}$, respectively as shown in Figure 5A. We next determined the effect of Equol on apoptosis in neuronal cells. First, Equol displayed a protective effect on LPS-activated BV-2 cells, mediated N2a toxicity as shown by MTT assay, and also induced toxicity via the expression of pro- and anti-apoptotic proteins in LPS-stimulated BV-2 cells. Equol decreased the expression of Bax and cleaved caspase-3 in a dose dependent manner. LPS treated group was made as $100 \%$ against untreated control. Equol treated conditioned medium dramatically reduced the expression of Bax by $67.45 \% \pm 1.46 \%, 48.16 \% \pm 1.23 \%, 33.84 \% \pm 1.04 \%$ and $18.82 \% \pm 0.83 \%$ at the concentration of $1,5,10$ and $20 \mu \mathrm{M}$. Similarly, the treatment reduced the expression of cleaved caspase- 3 by $56.87 \% \pm 0.38 \%, 42.82 \% \pm 1.64 \%, 30.76 \% \pm 0.69 \%$ and $33.44 \% \pm 0.55 \%$. This value is lower than the untreated control too. Furthermore, Equol upregulates the expression of an anti-apoptotic protein Bcl2 from $100.0 \% \pm 1.01 \%$ in LPS to $127.40 \% \pm 7.20 \%$ and $129.60 \% \pm 4.06 \%$ with the treatment of 10 and $20 \mu \mathrm{M}$ as shown in Figure 5B-E. The dramatic change in the expression of pro-apoptotic and anti-apoptotic protein with the treatment of Equol, proved its neuroprotective effect. These results clearly suggest the neuroprotective effects of Equol in LPS-activated neuroinflammatory conditions.

\subsection{Effect of Equol on Neurite Outgrowth in N2a Cells}

N2a cells were treated with different concentrations of Equol and retinoic acid, and neurite outgrowth was evaluated. N2a cells cease to proliferate and begin to differentiate, as shown by neurite outgrowth, in response to serum starvation, retinoic acid, or growth factors such as neurotrophins and glial cell-derived neurotrophic factor family ligands, as shown in Figure 6A. Neurite length was measured using an IncuCyte imaging system until $24 \mathrm{~h}$ after treatment. Equol dose-dependently increased neurite length compared with untreated cells as shown in Figure 6B,C.

\subsection{Effect of Equol on NGF Production in C6 Cells}

In the neuronal defense system, once an antigen or inflammatory pathogen triggers the immune system, activated microglia produce a variety of inflammatory mediators to protect the brain from the pathogen. Among cells that protect the brain, astrocytes produce inflammatory cytokines as well as nerve growth factors to protect neuronal cells and to maintain homeostasis in the brain. Therefore, a compound that increases the production of NGF by activating astrocytes may also possess potential 
for neuroprotection. To measure NGF content in the medium, C6 cells were seeded onto 24 well plates and treated with different concentrations of Equol. NGF release in the medium was determined using an ELISA kit to confirm NGF protein expression in cells. Equol concentration dependently increased NGF levels to $103.81 \% \pm 10.73 \%, 112.11 \% \pm 3.46 \%, 118.48 \% \pm 8.85 \%$, and $123.5 \% \pm 2.82 \%$ at concentrations of $1,5,10$, and $20 \mu \mathrm{M}$, respectively, in a medium without cellular toxicity as shown in Figure 6D,E respectively.
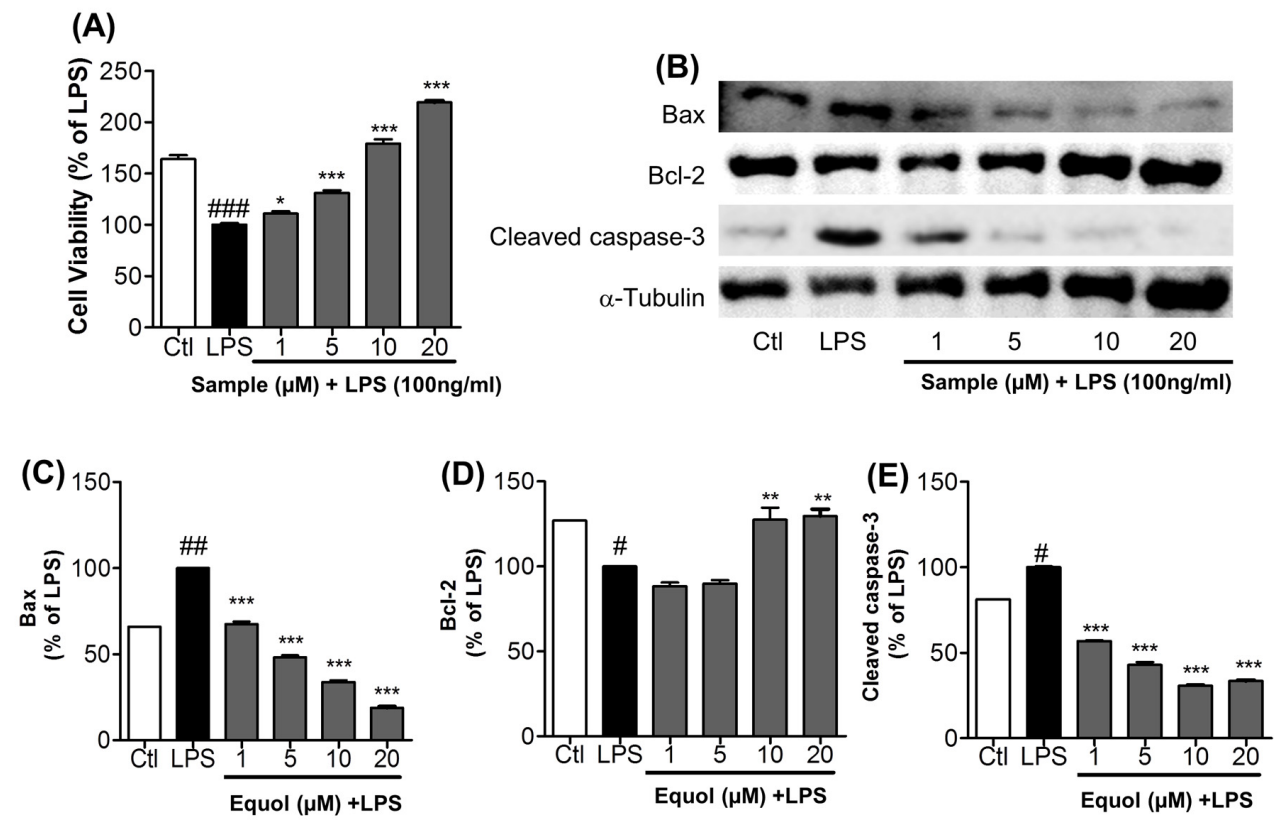

Figure 5. Effect of Equol on activated microglia-induced neurotoxicity in N2a cells. BV-2 microglial cells were pretreated with 1, 5, 10, or $20 \mu \mathrm{M}$ of Equol for $30 \mathrm{~min}$ and stimulated with LPS (100 ng/mL) for $24 \mathrm{~h}$. After $24 \mathrm{~h}$ of LPS treatment, the culture medium was collected and transferred to dishes plated with N2a cells. (A) Cell viability in N2a cells after $24 \mathrm{~h}$ treatment of LPS activated microglia treated media. Cell lysates were prepared in order to evaluate protein levels of apoptosis-related factors; (B) The expression of Bax, Bcl-2 and cleaved caspase-3 (C-E) Band intensity for above mentioned proteins respectively. $\alpha$-Tubulin was used as the loading control. Data represent the mean $\pm \mathrm{SEM}$ of three independent experiments performed in triplicate. ${ }^{*} p<0.05,{ }^{* *} p<0.01,{ }^{* * *} p<0.001$ vs. LPS-treated group and ${ }^{\#} p<0.05,{ }^{\# \#} p<0.01,{ }^{\# \#} p<0.001$ vs. untreated control group.

\section{(A)}
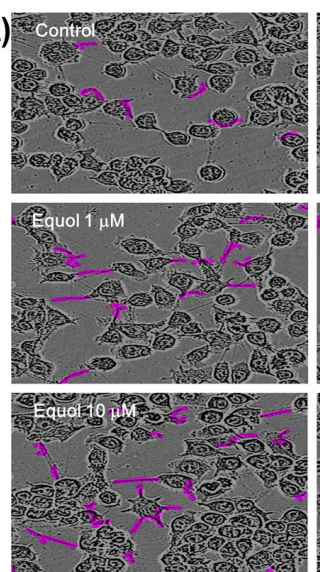
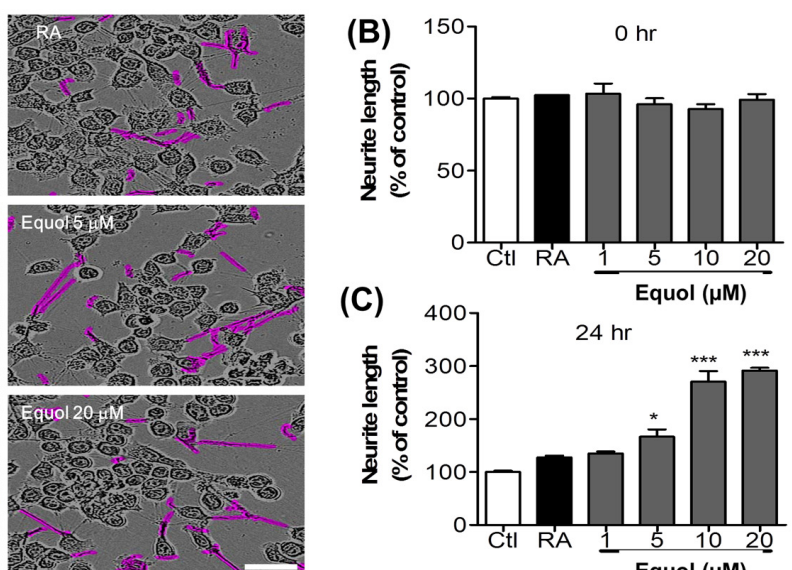

(C)

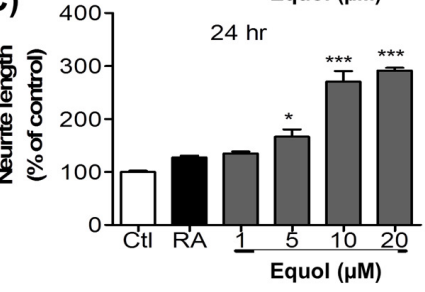

Figure 6. Cont. 
(D)

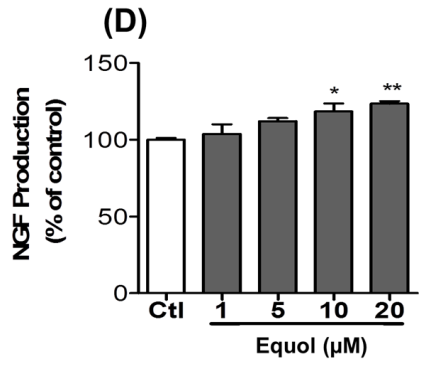

(E)

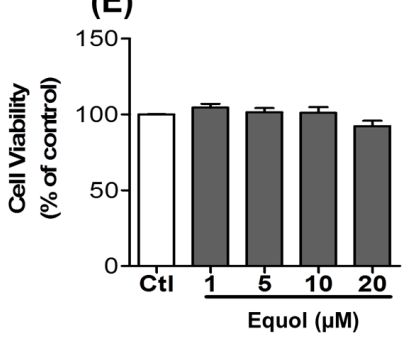

Figure 6. Effect of Equol on neurite outgrowth production in N2a cells and NGF production in C6 cells for neuroprotection. Neurite length in N2a cells was measured at regular intervals over a time span of $24 \mathrm{~h}$ after Equol $(1,5,10$, and $20 \mu \mathrm{M})$ treatment and images of cells were taken at the end of $24 \mathrm{~h}$. (A) Neuronal cell morphology during treatment; Neurite outgrowth is shown in pink (scale bar $=50 \mu \mathrm{M})($ B) Neurite length prior to treatment; (C) Neurite length after $24 \mathrm{~h}$ of treatment. Retinoic acid $(10 \mu \mathrm{M})$ treatment was used as a positive control to stimulate neurite outgrowth. Retinoic Acid (RA) was used as a positive control. C6 cells were treated with Equol at concentrations of 1, 5, 10, and $20 \mu \mathrm{M}$, respectively. After $24 \mathrm{~h}$, the amount of NGF produced by C6 cells was measured by ELISA; (D) NGF production in C6 glioma cells; (E) Cell viability of C6 cells during NGF production after $24 \mathrm{~h}$ of compound treatment. The data shown represent the mean \pm SEM of three independent experiments performed in triplicate. ${ }^{*} p<0.05,{ }^{* *} p<0.01,{ }^{* * *} p<0.001$ vs. untreated control group.

\section{Discussion}

Estrogen shows neuroprotective effects by enhancing glia-neuron crosstalk [28]. Neuronal cell death caused by oxidative stress contributes to the pathogenesis of neurodegenerative diseases, such as Alzheimer's disease and Parkinson's disease. Because they contain high amounts of phenolic compounds, unsaturated oils and proteins, soybeans are a food with high nutritional value as well as antioxidant and anticancer properties due to their active metabolites [9]. Previous studies reported that soybean isoflavones may also have neuroprotective effects due to their strong antioxidant and anti-inflammatory activities [40]. Neuroprotective effects of phytoestrogens, especially Equol, were reported in cerebral ischemia, but the detailed mechanisms are not yet clear [41,42]. Additionally, Genistein was reported to have higher antioxidant activity than Daidzein because it has the same B-ring structure, but also has one more hydroxyl group on its A/C-ring. Because of this, Daidzein is more lipophilic than Genistein, which could compensate for Daidzein's lower radical quenching capacity. Additionally, a Daidzein gut metabolite, Equol, is more soluble in organic solvents than Daidzein, meaning the bioavailability of Equol may be higher than that of Daidzein. Equol may be better in many aspects of biological activity than Genistein and Daidzein [43]. To find an effective therapeutic agent for the treatment of neurodegenerative diseases, including Alzheimer's disease, it is essential to consider structures with good blood brain barrier (BBB)-permeability. Considering its chemical structure, Equol may have the better BBB-permeability than other phytoestrogen [11,44]. Therefore, in the present study, we reported the neuroprotective effect of Equol, a nonsteroidal estrogen produced by human metabolism, by targeting inhibition of LPS-induced microglial activation, neuroinflammation, and neuronal apoptosis.

Microglial cells that are part of the brain's defense system normally respond to neuronal damage and induce phagocytosis $[45,46]$. However, toxin-induced chronic activation of microglia can cause neuroinflammation, followed by neurodegeneration and neuronal apoptosis in the brain, by inducing the production of proinflammatory cytokines (TNF- $\alpha$ and IL-6) and other inflammatory mediators, including reactive oxygen species (ROS), NO, MAPKs (phosphorylation of ERK, JNK, and p38), iNOS, COX-2, PGE-2, and glutamate [47-49]. Previous reports suggested that microglia-stimulated iNOS activation was the primary source of $\mathrm{NO}$ in neuroinflammation [50]. Among various proinflammatory factors, NO is a significant harmful product released from activated microglia. As LPS is a TLR4 agonist, it activates this receptor and then initiates the cascade of inflammation in the microglial 
cells. In the first screening of the Daidzein derivative for NO production inhibition, Equol showed the most potent activity without cellular toxicity (Figure 1A,B). The IC50 value of Equol is lower than that of Genistein and Daidzein and positive control L-NMMA. Not only is the Equol the most potent among Daidzein derivative, but it is also more promising than the well-known positive control L-NMMA (Figure 1C). Similarly, pretreatment of cells with Equol effectively decreased the LPS-induced TLR4 activation (Figure 2F,G) as well as NO production in BV-2 murine microglia cells without cellular toxicity (Figure 2A,B). In our study, Genistein, Daidzein and Equol all displayed inhibition of NO production in LPS-induced microglia, but Genistein was more toxic to neuronal cells than Daidzein. Equol was found to have the most potential and was without cellular toxicity. Additionally, Equol remarkably decreased iNOS and COX-2 expression, together with TNF- $\alpha$ and IL-6 secretion, in LPS-activated microglia in a concentration dependent manner. Because MAPKs respond to LPS-mediated microglia activation and mediate proliferation, differentiation and cell survival [51], short-term ERK1/2 activation promotes neuronal growth, differentiation and survival [52]. These signaling pathways and phosphorylation directly affect the NF-KB mediated transcription of these inflammatory mediators [53]. Equol increased the phosphorylation of ERK. However, it decreased the phosphorylation of p38 and JNK. Equol showed the similar efficacy to inhibit the phosphorylation of JNK and TNF- $\alpha$ secretion in comparison with a well-known JNK inhibitor (SP600125). NF- $\mathrm{KB}$ is a very important inflammatory mediator, and a modulator of neuroinflammation for the proinflammatory cytokines, iNOS and COX-2, in LPS-activated microglial cells [37]. Therefore, we evaluated the effect ability of Equol in altering the activity of NF- $\mathrm{KB}$ for the production of a variety of inflammatory mediators and pro-inflammatory cytokines that are responsible for neuroinflammation and neurodegeneration. Equol significantly inhibited NF- $\mathrm{KB}$ mediated transcription of proinflammatory mediators via decreased phosphorylation of IкB with the pretreatment of BV-2 cells. These results indicated that Equol had strong anti-inflammatory potential in LPS-activated microglia via reduced TLR4 activation, JNK phosphorylation and proinflammatory cytokine, especially TNF- $\alpha$ secretion. As TLR4-JNK-NF- $\mathrm{KB}-\mathrm{TNF}-\alpha$ mediated inflammatory cascades are the well-known pathway for the activated microglia-induced neuronal death, we moved to find the role of Equol to prevent LPS-activated microglia-induced neuronal cell death.

The activated microglia directly damage the neurons and induce neuronal apoptosis through the regulation of inflammatory and cytotoxic factors, including NO, TNF- $\alpha$, IL- $1 \beta$, arachidonic acid, eicosanoids and ROS. These cytotoxic factors are the major cause of neuronal damage and neuronal apoptosis through regulation of the Bcl-2 family [54-56]. The Bcl-2 family consists of pro-apoptotic (Bax and cleaved caspase-3) and pro-survival (Bcl-2) proteins, which are responsible for the physical and functional interactions that regulate apoptosis [57]. This study also supported the idea that LPS-activated microglia increased the expression of Bax and cleaved caspase- 3 and downregulated Bcl-2 in neuronal cells, where Equol dramatically reversed the apoptotic properties of LPS-activated microglia cells and thereby protein expression in neuronal cells. Additionally, in support of an anti-apoptotic effect, Equol increased neuronal cell viability in LPS-activated microglia-induced neuronal death. These results suggested that Equol is a potent neuroprotective agent against LPS-stimulated neuronal death. Production of NO and increased COX-2, iNOS, PGE-2 and proinflammatory cytokines ultimately caused neuronal death. Neuronal death is mediated by increased pro-apoptotic proteins, such as Bax and cleaved caspase-3, and decreased pro-survival/anti-apoptotic proteins, such as Bcl-2.

Neuronal apoptosis is followed by high neurite loss after activated microglia-induced toxicity. This is one of the hallmarks of neuronal injury and neurodegeneration [58]. The neuronal immune system tried to adopt the neurite outgrowth and improve the functional recovery that is necessary for neuronal survival [59]. Apart from neuroprotection, reorganization of the lost neuronal network in the injured brain is necessary for the restoration of normal physiological function [60]. Natural compounds that restore neurite loss and promote neurite outgrowth may be considered potential neuroprotective agents [60]. In this study, Equol significantly increased neurite length and density relative to retinoic 
acid, demonstrating the strong neuroprotective efficacy of Equol in N2a cells. On the other hand, NGF, secreted by astrocytes, can repair inflammation-induced damage to neurons and prevent apoptotic neuronal cell death [61]. In this study, Equol substantially increased the secretion of NGF in C6 glioma cells, suggesting a neuroprotective effect.

\section{Conclusions}

In summary, Equol, a Daidzein gut metabolite, showed neuroprotective activity via downregulation of the LPS-induced neuroinflammation. It not only inhibited LPS-induced microglial activation, but also protected from neuroinflammatory injury through downregulation of neuronal apoptosis. Furthermore, it increased neurite outgrowth in neuronal cells and increased nerve growth in astrocytes. These results suggest that Equol may be a potential nutraceutical for neuroprotection via regulation of neuroinflammation, apoptosis, and neurotrophins.

Acknowledgments: This work was supported by a grant from the National Institute of Biological Resources (NIBR), funded by the Ministry of Environment (MOE) of the Republic of Korea (NIBR201627201) and partly the Korea Health Technology R\&D Project through the Korea Health Industry Development Institute (KHIDI), Ministry of Health \& Welfare (grant No. HI14C1135).

Author Contributions: Lalita Subedi designed the study and performed experiments. Eunhee Ji, Jongsik Jin, Dongyun Shin, Joo Hong Yeo and Lalita Subedi prepared the manuscript. Sun Yeou Kim conceptualized all this study and the experiments within, and also edited the manuscript.

Conflicts of Interest: The authors declare no conflict of interest.

\section{References}

1. Ullah, M.F.; Bhat, S.H.; Husain, E.; Abu-Duhier, F.; Hadi, S.M.; Sarkar, F.H.; Ahmad, A. Pharmacological Intervention through Dietary Nutraceuticals in Gastrointestinal Neoplasia. Crit. Rev. Food Sci. Nutr. 2016, 56, 1501-1518. [CrossRef] [PubMed]

2. Fura, A. Role of pharmacologically active metabolites in drug discovery and development. Drug Discov. Today 2006, 11, 133-142. [CrossRef]

3. Howes, M.J.; Perry, E. The role of phytochemicals in the treatment and prevention of dementia. Drugs Aging 2011, 28, 439-468. [CrossRef] [PubMed]

4. Ding, Y.; Zhou, X.; Zuo, L.; Wang, H.; Yu, D. Identification and functional characterization of the sulfate transporter gene GmSULTR1;2b in soybean. BMC Genom. 2016, 17, 373. [CrossRef] [PubMed]

5. Patisaul, H.B.; Jefferson, W. The pros and cons of phytoestrogens. Front. Neuroendocrinol. 2010, 31, 400-419. [CrossRef] [PubMed]

6. Sunita, P.; Pattanayak, S.P. Phytoestrogens in postmenopausal indications: A theoretical perspective. Pharmacogn. Rev. 2011, 5, 41-47. [CrossRef] [PubMed]

7. Bacciottini, L.; Falchetti, A.; Pampaloni, B.; Bartolini, E.; Carossino, A.M.; Brandi, M.L. Phytoestrogens: Food or drug? Clin. Cases Miner. Bone Metab. 2007, 4, 123-130. [PubMed]

8. Vitale, D.C.; Piazza, C.; Melilli, B.; Drago, F.; Salomone, S. Isoflavones: Estrogenic activity, biological effect and bioavailability. Eur. J. Drug Metab. Pharmacokinet. 2013, 38, 15-25. [CrossRef] [PubMed]

9. Liu, J.; Yang, C.Q.; Zhang, Q.; Lou, Y.; Wu, H.J.; Deng, J.C.; Yang, F.; Yang, W.Y. Partial improvements in the flavor quality of soybean seeds using intercropping systems with appropriate shading. Food Chem. 2016, 207, 107-114. [CrossRef] [PubMed]

10. Gadgeel, S.M.; Ali, S.; Philip, P.A.; Wozniak, A.; Sarkar, F.H. Genistein enhances the effect of epidermal growth factor receptor tyrosine kinase inhibitors and inhibits nuclear factor kappa B in nonsmall cell lung cancer cell lines. Cancer 2009, 115, 2165-2176. [CrossRef] [PubMed]

11. Schreihofer, D.A.; Redmond, L. Soy phytoestrogens are neuroprotective against stroke-like injury in vitro. Neuroscience 2009, 158, 602-609. [CrossRef] [PubMed]

12. Ma, W.; Ding, B.; Yu, H.; Yuan, L.; Xi, Y.; Xiao, R. Genistein alleviates beta-amyloid-induced inflammatory damage through regulating Toll-like receptor 4/nuclear factor kappaB. J. Med. Food 2015, 18, 273-279. [CrossRef] [PubMed] 
13. Setchell, K.D.; Brown, N.M.; Zhao, X.; Lindley, S.L.; Heubi, J.E.; King, E.C.; Messina, M.J. Soy isoflavone phase II metabolism differs between rodents and humans: Implications for the effect on breast cancer risk. Am. J. Clin. Nutr. 2011, 94, 1284-1294. [CrossRef] [PubMed]

14. Rozman, K.K.; Bhatia, J.; Calafat, A.M.; Chambers, C.; Culty, M.; Etzel, R.A.; Flaws, J.A.; Hansen, D.K.; Hoyer, P.B.; Jeffery, E.H.; et al. NTP-CERHR expert panel report on the reproductive and developmental toxicity of soy formula. Birth Defects Res. Part B Dev. Reprod. Toxicol. 2006, 77, 280-397. [CrossRef] [PubMed]

15. Miousse, I.R.; Sharma, N.; Blackburn, M.; Vantrease, J.; Gomez-Acevedo, H.; Hennings, L.; Shankar, K.; Cleves, M.A.; Badger, T.M.; Ronis, M.J. Feeding soy protein isolate and treatment with estradiol have different effects on mammary gland morphology and gene expression in weanling male and female rats. Physiol. Genom. 2013, 45, 1072-1083. [CrossRef] [PubMed]

16. Setchell, K.D.; Cole, S.J. Method of defining equol-producer status and its frequency among vegetarians. J. Nutr. 2006, 136, 2188-2193. [PubMed]

17. Tousen, Y.; Uehara, M.; Abe, F.; Kimira, Y.; Ishimi, Y. Effects of short-term fructooligosaccharide intake on equol production in Japanese postmenopausal women consuming soy isoflavone supplements: A pilot study. Nutr. J. 2013, 12, 127. [CrossRef] [PubMed]

18. Matthies, A.; Loh, G.; Blaut, M.; Braune, A. Daidzein and genistein are converted to equol and 5-hydroxy-equol by human intestinal Slackia isoflavoniconvertens in gnotobiotic rats. J. Nutr. 2012, 142, 40-46. [CrossRef] [PubMed]

19. Frankenfeld, C.L.; Atkinson, C.; Wahala, K.; Lampe, J.W. Obesity prevalence in relation to gut microbial environments capable of producing equol or $O$-desmethylangolensin from the isoflavone daidzein. Eur. J. Clin. Nutr. 2014, 68, 526-530. [CrossRef] [PubMed]

20. Choi, E.J.; Ahn, W.S.; Bae, S.M. Equol induces apoptosis through cytochrome c-mediated caspases cascade in human breast cancer MDA-MB-453 cells. Chem. Biol. Interact. 2009, 177, 7-11. [CrossRef] [PubMed]

21. Poluzzi, E.; Piccinni, C.; Raschi, E.; Rampa, A.; Recanatini, M.; de Ponti, F. Phytoestrogens in postmenopause: The state of the art from a chemical, pharmacological and regulatory perspective. Curr. Med. Chem. 2014, 21, 417-436. [CrossRef] [PubMed]

22. Cegiela, U.; Folwarczna, J.; Pytlik, M.; Zgorka, G. Effects of extracts from trifolium medium L. and Trifolium pratense L. on development of estrogen deficiency-induced osteoporosis in rats. Evid. Based Complement. Altern. Med. eCAM 2012, 2012, 921684. [CrossRef] [PubMed]

23. Setchell, K.D.; Zhao, X.; Jha, P.; Heubi, J.E.; Brown, N.M. The pharmacokinetic behavior of the soy isoflavone metabolite $\mathrm{S}-(-)$ equol and its diastereoisomer R-(+)equol in healthy adults determined by using stable-isotope-labeled tracers. Am. J. Clin. Nutr. 2009, 90, 1029-1037. [CrossRef] [PubMed]

24. Mahmoud, A.M.; Yang, W.; Bosland, M.C. Soy isoflavones and prostate cancer: A review of molecular mechanisms. J. Steroid Biochem. Mol. Biol. 2014, 140, 116-132. [CrossRef] [PubMed]

25. Ma, Y.; Sullivan, J.C.; Schreihofer, D.A. Dietary genistein and equol (4', 7 isoflavandiol) reduce oxidative stress and protect rats against focal cerebral ischemia. Am. J. Physiol. Regul. Integr. Comp. Physiol. 2010, 299, R871-R877. [CrossRef] [PubMed]

26. Uehara, M. Isoflavone metabolism and bone-sparing effects of daidzein-metabolites. J. Clin. Biochem. Nutr. 2013, 52, 193-201. [CrossRef] [PubMed]

27. Zhou, C.; Huang, Y.; Przedborski, S. Oxidative stress in Parkinson's disease: A mechanism of pathogenic and therapeutic significance. Ann. N. Y. Acad. Sci. 2008, 1147, 93-104. [CrossRef] [PubMed]

28. Morale, M.C.; Serra, P.A.; L'Episcopo, F.; Tirolo, C.; Caniglia, S.; Testa, N.; Gennuso, F.; Giaquinta, G.; Rocchitta, G.; Desole, M.S.; et al. Estrogen, neuroinflammation and neuroprotection in Parkinson's disease: Glia dictates resistance versus vulnerability to neurodegeneration. Neuroscience 2006, 138, 869-878. [CrossRef] [PubMed]

29. Chai, N.C.; Peterlin, B.L.; Calhoun, A.H. Migraine and estrogen. Curr. Opin. Neurol. 2014, 27, $315-324$. [CrossRef] [PubMed]

30. Ravn, S.H.; Rosenberg, J.; Bostofte, E. Postmenopausal hormone replacement therapy-Clinical implications. Eur. J. Obstet. Gynecol. Reprod. Biol. 1994, 53, 81-93. [CrossRef]

31. Perez-Cano, F.J.; Castell, M. Flavonoids, Inflammation and Immune System. Nutrients 2016, 8, 659. [CrossRef] [PubMed]

32. Yu, J.; Bi, X.; Yu, B.; Chen, D. Isoflavones: Anti-inflammatory benefit and possible caveats. Nutrients 2016, 8, 361. [CrossRef] [PubMed] 
33. Medjakovic, S.; Mueller, M.; Jungbauer, A. Potential health-modulating effects of isoflavones and metabolites via activation of PPAR and AhR. Nutrients 2010, 2, 241-279. [CrossRef] [PubMed]

34. Catley, M.C.; Birrell, M.A.; Hardaker, E.L.; de Alba, J.; Farrow, S.; Haj-Yahia, S.; Belvisi, M.G. Estrogen receptor beta: Expression profile and possible anti-inflammatory role in disease. J. Pharmacol. Exp. Ther. 2008, 326, 83-88. [CrossRef] [PubMed]

35. Catorce, M.N.; Gevorkian, G. LPS-inducedmurine neuroinflammation model: Main features and suitability for pre-clinical assessment of Nutraceuticals. Curr. Neuropharmacol. 2016, 14, 155-164. [CrossRef] [PubMed]

36. Qin, L.; Wu, X.; Block, M.L.; Liu, Y.; Breese, G.R.; Hong, J.S.; Knapp, D.J.; Crews, F.T. Systemic LPS causes chronic neuroinflammation and progressive neurodegeneration. Glia 2007, 55, 453-462. [CrossRef] [PubMed]

37. Ha, S.K.; Moon, E.; Ju, M.S.; Kim, D.H.; Ryu, J.H.; Oh, M.S.; Kim, S.Y. 6-Shogaol, a ginger product, modulates neuroinflammation: A new approach to neuroprotection. Neuropharmacology 2012, 63, 211-223. [CrossRef] [PubMed]

38. Subedi, L.; Gaire, B.P.; Do, M.H.; Lee, T.H.; Kim, S.Y. Anti-neuroinflammatory and neuroprotective effects of the Lindera neesiana fruit in vitro. Phytomedicine 2016, 23, 872-881. [CrossRef] [PubMed]

39. Reif, D.W.; McCreedy, S.A. N-nitro-L-arginine and N-monomethyl-L-arginine exhibit a different pattern of inactivation toward the three nitric oxide synthases. Arch. Biochem. Biophys. 1995, 320, 170-176. [CrossRef]

40. Pandey, K.B.; Rizvi, S.I. Plant polyphenols as dietary antioxidants in human health and disease. Oxid. Med. Cell. Longev. 2009, 2, 270-278. [CrossRef] [PubMed]

41. Wang, C.N.; Chi, C.W.; Lin, Y.L.; Chen, C.F.; Shiao, Y.J. The neuroprotective effects of phytoestrogens on amyloid beta protein-induced toxicity are mediated by abrogating the activation of caspase cascade in rat cortical neurons. J. Biol. Chem. 2001, 276, 5287-5295. [CrossRef] [PubMed]

42. Yu, W.; Wang, Y.; Zhou, D.X.; Zhao, L.M.; Li, G.R.; Deng, X.L. Equol is neuroprotective during focal cerebral ischemia and reperfusion that involves p-Src and gp91(phox). Curr. Neurovasc. Res. 2014, 11, 367-377. [CrossRef] [PubMed]

43. Del Rio, D.; Rodriguez-Mateos, A.; Spencer, J.P.; Tognolini, M.; Borges, G.; Crozier, A. Dietary (poly)phenolics in human health: Structures, bioavailability, and evidence of protective effects against chronic diseases. Antioxid. Redox Signal. 2013, 18, 1818-1892. [CrossRef] [PubMed]

44. Sareddy, G.R.; Nair, B.C.; Gonugunta, V.K.; Zhang, Q.G.; Brenner, A.; Brann, D.W.; Tekmal, R.R.; Vadlamudi, R.K. Therapeutic significance of estrogen receptor beta agonists in gliomas. Mol. Cancer Ther. 2012, 11, 1174-1182. [CrossRef] [PubMed]

45. Block, M.L.; Hong, J.S. Microglia and inflammation-mediated neurodegeneration: Multiple triggers with a common mechanism. Prog. Neurobiol. 2005, 76, 77-98. [CrossRef] [PubMed]

46. Park, J.S.; Shin, J.A.; Jung, J.S.; Hyun, J.W.; Van Le, T.K.; Kim, D.H.; Park, E.M.; Kim, H.S. Anti-inflammatory mechanism of compound $\mathrm{K}$ in activated microglia and its neuroprotective effect on experimental stroke in mice. J. Pharmacol. Exp. Ther. 2012, 341, 59-67. [CrossRef] [PubMed]

47. Schett, G.; Tohidast-Akrad, M.; Smolen, J.S.; Schmid, B.J.; Steiner, C.W.; Bitzan, P.; Zenz, P.; Redlich, K.; $\mathrm{Xu}, \mathrm{Q}$.; Steiner, G. Activation, differential localization, and regulation of the stress-activated protein kinases, extracellular signal-regulated kinase, c-JUN N-terminal kinase, and p38 mitogen-activated protein kinase, in synovial tissue and cells in rheumatoid arthritis. Arthritis Rheum. 2000, 43, 2501-2512. [CrossRef]

48. Koide, Y.; Ito, A.; Edo, K.; Ishida, N. The biologically active site of neocarzinostatin-chromophore. Chem. Pharm. Bull. 1986, 34, 4425-4428. [CrossRef] [PubMed]

49. Dheen, S.T.; Kaur, C.; Ling, E.A. Microglial activation and its implications in the brain diseases. Curr. Med. Chem. 2007, 14, 1189-1197. [CrossRef] [PubMed]

50. Marques, C.P.; Cheeran, M.C.; Palmquist, J.M.; Hu, S.; Lokensgard, J.R. Microglia are the major cellular source of inducible nitric oxide synthase during experimental herpes encephalitis. J. Neurovirol. 2008, 14, 229-238. [CrossRef] [PubMed]

51. Munshi, A.; Ramesh, R. Mitogen-activated protein kinases and their role in radiation response. Genes Cancer 2013, 4, 401-408. [CrossRef] [PubMed]

52. Schurer, L.; Grogaard, B.; Gerdin, B.; Arfors, K.E. Effects of neutrophil depletion and superoxide dismutase on postischemic hypoperfusion of rat brain. Adv. Neurol. 1990, 52, 57-62. [PubMed]

53. Lawrence, T. The nuclear factor NF-kappaB pathway in inflammation. Cold Spring Harb. Perspect. Biol. 2009, 1, a001651. [CrossRef] [PubMed] 
54. Chen, Z.; Jalabi, W.; Shpargel, K.B.; Farabaugh, K.T.; Dutta, R.; Yin, X.; Kidd, G.J.; Bergmann, C.C.; Stohlman, S.A.; Trapp, B.D. Lipopolysaccharide-induced microglial activation and neuroprotection against experimental brain injury is independent of hematogenous TLR4. J. Neurosci. 2012, 32, 11706-11715. [CrossRef] [PubMed]

55. Ke, L.; Guo, W.; Xu, J.; Zhang, G.; Wang, W.; Huang, W. Ginsenoside Rb1 attenuates activated microglia-induced neuronal damage. Neural Regen. Res. 2014, 9, 252-259. [PubMed]

56. Guadagno, J.; Xu, X.; Karajgikar, M.; Brown, A.; Cregan, S.P. Microglia-derived TNFalpha induces apoptosis in neural precursor cells via transcriptional activation of the Bcl-2 family member Puma. Cell Death Dis. 2013, 4, e538. [CrossRef] [PubMed]

57. Youle, R.J.; Strasser, A. The BCL-2 protein family: Opposing activities that mediate cell death. Nat. Rev. Mol. Cell Biol. 2008, 9, 47-59. [CrossRef] [PubMed]

58. Ferguson, T.A.; Scherer, S.S. Neuronal cadherin (NCAD) increases sensory neurite formation and outgrowth on astrocytes. Neurosci. Lett. 2012, 522, 108-112. [CrossRef] [PubMed]

59. Jayaraman, A.; Lent-Schochet, D.; Pike, C.J. Diet-induced obesity and low testosterone increase neuroinflammation and impair neural function. J. Neuroinflamm. 2014, 11, 162. [CrossRef] [PubMed]

60. More, S.V.; Koppula, S.; Kim, I.S.; Kumar, H.; Kim, B.W.; Choi, D.K. The role of bioactive compounds on the promotion of neurite outgrowth. Molecules 2012, 17, 6728-6753. [CrossRef] [PubMed]

61. Williams, K.S.; Killebrew, D.A.; Clary, G.P.; Meeker, R.B. Opposing Effects of NGF and proNGF on HIV Induced Macrophage Activation. J. Neuroimmune Pharmacol. 2016, 11, 98-120. [CrossRef] [PubMed]

(C) 2017 by the authors. Licensee MDPI, Basel, Switzerland. This article is an open access article distributed under the terms and conditions of the Creative Commons Attribution (CC BY) license (http:/ / creativecommons.org/licenses/by/4.0/). 